Canadian University Music Review

Canadian University Music Review

Revue de musique des universités canadiennes

\title{
Beginning Harmony: the Post-Schenkerian Dilemma
}

\section{Christopher Lewis}

Volume 9, numéro 1, 1988

URI : https://id.erudit.org/iderudit/1014926ar

DOI : https://doi.org/10.7202/1014926ar

Aller au sommaire du numéro

Éditeur(s)

Canadian University Music Society / Société de musique des universités

canadiennes

ISSN

0710-0353 (imprimé)

2291-2436 (numérique)

Découvrir la revue

Citer cet article

Lewis, C. (1988). Beginning Harmony: the Post-Schenkerian Dilemma. Canadian University Music Review / Revue de musique des universités canadiennes, 9(1),

136-156. https://doi.org/10.7202/1014926ar

All Rights Reserved @ Canadian University Music Society / Société de musique des universités canadiennes, 1988
Ce document est protégé par la loi sur le droit d'auteur. L'utilisation des services d'Érudit (y compris la reproduction) est assujettie à sa politique d'utilisation que vous pouvez consulter en ligne.

https://apropos.erudit.org/fr/usagers/politique-dutilisation/ 


\section{BEGINNING HARMONY: THE POST-SCHENKERIAN DILEMMA}

\section{Christopher Lewis}

It is now more than fifty years since the death of Heinrich Schenker. The academic debate over the legitimacy of his work is essentially over, and his theories are recognized by those who know them as the most important body of theoretical musical thought of this century. Schenkerian theory has profoundly changed graduate study in the theory of music on this continent in the last twenty-five years, yet it seems we are still very unsure how to incorporate it into our undergraduate curricula. Both theory textbooks and articles on the pedagogy of theory reflect the breadth of current views. Texts range from the staunchly traditional (Kostka \& Payne 1984) through the subliminally linear (Aldwell \& Schachter 1978) to the aggressively Schenkerian (Lester 1982), and recent articles by leading practitioners of Schenkerian analysis reach radically different conclusions about the undergraduate curriculum (Beach 1983, Rothgeb 1981).

Curiously enough, even works owing a heavy debt to Schenker's theories seem almost embarrassed by the Ursatz. Der Freie Satz itself begins with a three-chapter discussion of the background stratum. Schenker considers the background an indispensable prerequisite to a work of art (Schenker 1978:3-4), and gives philosophic and technical justifications for his point of view. Oswald Jonas's presentation of Schenker's theory (Jonas 1982) reverses the order in which background and foreground are discussed, but since his book antedates Schenker's, the difference is certainly understandable. What is curious is that Jonas' plan began a virtually unbroken pedagogical tradition, followed even by the most 
recent Schenkerian text (Forte \& Gilbert 1982). Now, there are necessarily crucial differences between a theoretical treatise - or even an advanced text - and a text for beginning students. The one is aimed at mature musicians, the other at neophytes; the one presents a monistic theoretical disquisition, the other lays a broad foundation of musical understandings; the one can be highly abstract and technical, the other must necessarily be propadeutic. Nonetheless, the delay of a discussion of background may seriously undermine comprehension of the Schenkerian position. If Schenker was right in believing that his theories presented for the first time a genuine theory of tonal language (Schenker 1978 vol.I:9) - that is, a precise way of defining what is, and what is not, tonal - there is no reason for university instructors to continue our longstanding practice of lecturing to our students for two or three years about tonal music without ever attempting to define tonality accurately, either for the students or for ourselves. Too often, we have simply hoped that students will eventually intuit what is meant by "tonal harmony" or "tonal counterpoint" from a mass of empirical data and unnecessarily restrictive "rules," even when the rules are largely pedagogical conveniences far removed from actual compositional practice. But another approach is possible, if Schenker is right in proposing that the essence of tonal music is not just in chord-tochord progressions, or in principles of voice-leading (most of which in any case derive from pretonal practice), but rather in a compositional coherence which can be achieved "only through the Fundamental Structure in the background, and its transformations in the middleground and foreground" (Schenker 1978 vol.I:6).

A beautiful example of how background helps clarify the foreground, and vice versa is found in the opening measures of Beethoven's Op. 101 (see Example 1). At first glance, the excerpt seems to exemplify tonality without a Schenkerian Ursatz: there is no tonic chord directly supporting a reasonable candidate for Kopfton. But if we accept the Schenkerian definition of tonality, and if we understand the degree to which the Ursatz is an abstraction, not always to be revealed by simply stripping away passing and neighbouring tones, then we can easily understand that the tonic chord of m.3 does indeed support a Kopfton 3. That note answers the question "Where does the chordal seventh in 
m.2 resolve?" and"What prepares the $6 / 4$ suspension of m.4?" The irregular chord progression disappears, subsumed by the tonic harmony, and we find that the whole phrase actually derives from the elaboration of the background sonority which never literally appears. Of course, our simple line of reasoning can be reversed and we can use our knowledge of voice-leading to take us from the peculiarities of the surface to the ultimate simplicity of the background. In actual analysis, we probably work both ways at once. In any case, we can understand that $\mathrm{Op} .101$ is tonal precisely because its voice-leadings $d o$ elaborate a common-practice Ursatz.

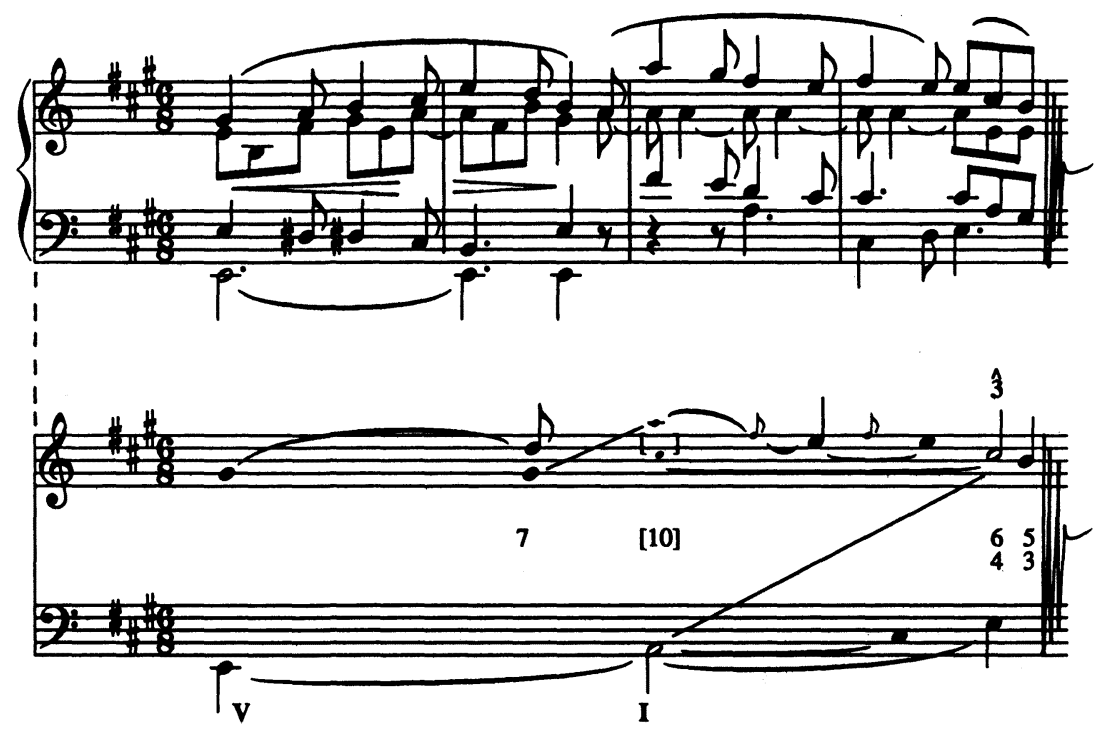

Figure 1. : Beethoven, Op. 101/I, mm. 1-4 :

This, then, is the post-Schenkeraian pedagogical dilemma: we seem unable to escape the conclusion that when we teach "tonal harmony" we are teaching Schenkerian theory in some sense, since we are teaching a style defined in Schenkerian terms. But while Schenker might well 
accuse me and my department of "expediency" (Schenker 1978 vol.I:ix), we have not adopted a core curriculum allowing several years of preliminary technical work culminating in a course in Schenkerian analysis; nor can I see any prospect of the general adoption of such a plan. ${ }^{1}$

It is rare indeed to find more than three years of core theory study, and surely a significant part of that time must be devoted to the very diverse musics of our own rapidly waning century. To plan an undergraduate theory curriculum without a strong twentieth-century component is inexcusable dereliction of responsibility. The virtual exclusion from the theory classroom of any formal investigation of the vast pre-tonal literature is hardly less lamentable, but at least in doing so we do not abandon our colleagues, the still-living composers we all depend upon for continuing musical regeneration. ${ }^{2}$ How best, then, can we serve the incipient performers, theorists, composers, teachers, musicologists and - dare we admit it? - listeners who sit in our classrooms? If we can devote at most two compulsory years to the study of tonal theory, we surely have the responsibility of including in that short time as much actual music, and as much analysis of that music, as possible. Classroom work simply cannot be restricted to technical "hothouse" exercises - not to the writing of ersatz chorales, not to the writing of figured bass exercises, not to the writing of Fuxian counterpoint. The goal of the music theory program is not the training of composers of tonal music, as was once the case, but the encouragement of musical literacy within the strictures of a broadly based, but narrowly regulated, humanistic curriculum.

1 John Rothgeb disagrees. He proposes "one full year of study of strict counterpoint and figured bass, with little if any reference to inversion theory or Roman numerals. During the second year, harmony can be introduced, chiefly as an analytical concept ... the curriculum I have described is an impractical one only because it is so different from any in existence, and because no correspondingly organized modern textbook has been written" (Rothgeb 1981:149).

2 Some texts do attempt to address this problem. Perhaps the most comprehensive and useful is Kraft (1987). 
Real Schenkerian analytic theory is a subtle and complicated system of musical thought for the study of which few, if any, college freshmen are musically or intellectually prepared. I take it as a truism that such study must be preceded by a foundation in traditional analysis, as well as by training in counterpoint and harmony (Beach 1983:3). Therefore, we must develop ways of teaching tonal harmony - the musical syntax defined so beautifully for us by Schenker - without actually teaching a freshman course in Schenkerian analysis. We should be able to teach the concepts of structural levels, of the existence of structural and prolongational events, of the difference between "chord" and "harmony," of the compositional coherence created by the transformations of the fundamental structure in the middleground and foreground, without requiring the drafting of complex analytic graphs.

Schenker, impelled by his nineteenth-century German view of education and of cultural development, believed that the structure of musical pedagogy should derive from the simple chronology of history. Only a plan which "corresponds exactly to the history and development of the masterworks" can be a "feasible sequence for instruction" (Schenker 1978 vol.I:xxi). But such a view requires that artistic change and the acquisition of knowledge both be finite, terminable processes. It implies that the more we learn of history, the more we must become entangled in the complications of the past; that the accidents of history will have precedence over our rational powers of analysis and synthesis; and that an obsession with the idea that the masterworks of the tonal period represent the culmination of a progress to artistic truth will blind us to any sense of historical perspective on the art of our own century. ${ }^{3}$

The instructor of undergraduates has not to instill in his students all the technical skills that were once essential to the training of a composer of tonal music (which is unnecessary), nor to teach them to imitate or to analyse fully the great masterworks (which is impossible). Rather, he must distill from a frighteningly vast and complex body of material what is possible and relevant for the students to learn, and find some

3 Schenker himself was of course so blinded. That is, however, no argument against the validity of his views of the common practice: one does not expect a prophet to be also a student of comparative religion. 
way to lead them to it in a relatively short time. For a few students, this instruction will not be the sole theoretical training, but merely the foundation for more advanced study.

It may be argued that beginning students should not grapple at all with these concepts, the mere idea of which escaped many generations of brilliant theorists (Rothgeb 1981:148). But the whole history of learning refutes this view. The principle of multiplication now taught in our primary schools was not developed until the mid-fifteenth century. The differential calculus was understood by none of the great mathematicians before Newton, but is now routinely taught to gifted high school students. That a beginning university student is not ready for all of Schenker's theory (because she does not have the technical background, knowledge of the repertoire, and analytic experience for a course in Schenkerian analysis) does not mean that she should not be taught harmony, figured bass, voice-leading, counterpoint, and form in a manner informed by that theory. The freshman or sophomore cannot graph the Mozart sonata movement she is preparing for her piano lessons, but she can and should be taught to make some of the analytic distinctions deriving from the theory of structural and prolongational events: she can be taught to think about tonal music in a Schenkerian way, if not with a developed Schenkerian technique.

Very often the problems of understanding the more sophisticated concepts in a freshman class are not those of the beginning student, but of students who have already had some harmony instruction which invariably has to be "counter-taught" by the university instructor. The phenomenon is much more common in Canada than in the United States, since the majority of Canadian music majors while still in high school have been put through the curriculum of one of the conservatories or preparatory schools. At best only loosely affiliated with a university, these musical out-patient clinics offer courses of study and standard examinations; the curricula in theory are necessarily designed so they may be taught by a teacher with little theoretical training, and they often saddle the student with a terrible encumbrance of useless misconceptions, faulty techniques and irrational terminologies. Until the curricula of the conservatories are drastically reformed, I will continue to prefer students who come to the university with a rigorous grounding in notational and taxonomical rudiments, and no more. 
a)

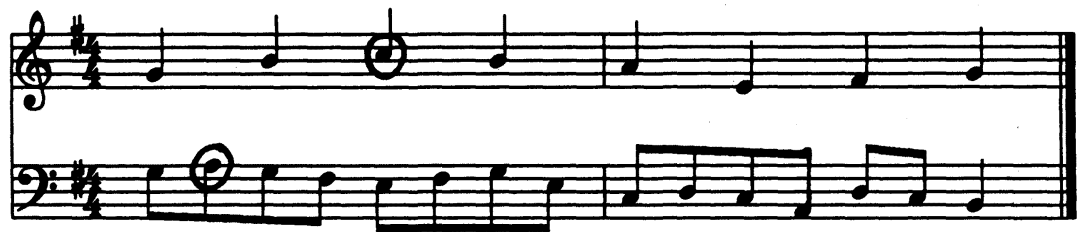

b) RodeLinda.

(Bassi.)

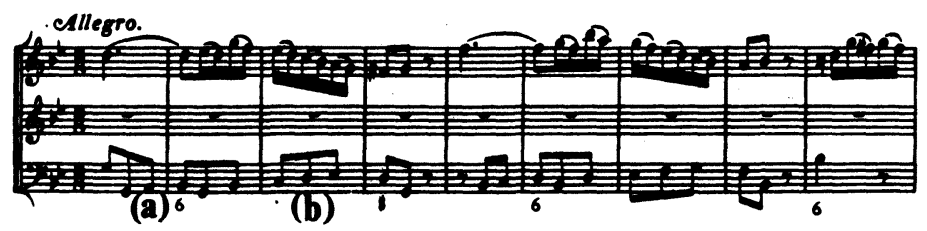

c)

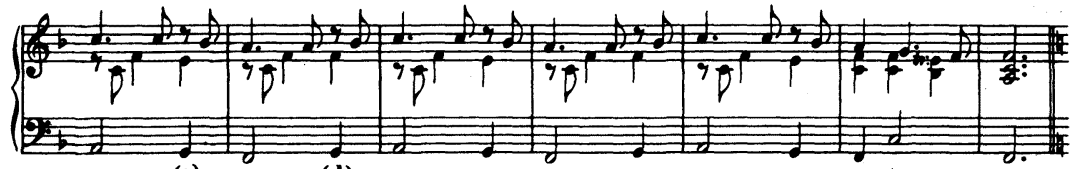

(c)

(d)

Figure 2. : a) Student exercises. b) Handel, "L'empio rigor del fato" from Rodelinda, mm. 1-9. c) Kuhnau, Biblische Sonate Nr. 5, mm. 174-180. : 
Example 2 shows three excerpts which demonstrate that even a freshman can begin to learn the distinction between a descriptive label and an analytic judgement, and, therefore, the difference between "chord" and "harmony." If the student is taught to hear musically and intelligently from the beginning, he will not run amok with a shotgun loaded with Roman numerals, peppering every "chord" in sight. Early problems with such discriminations do not arise from teaching the use of Roman numerals, which can be immensely useful, but from poor teaching about music.

Example 2a shows a two-part exercise composed by a student about four weeks into the first term of freshman theory. Previous classroom discussion and assignments have touched on melodic shape, conjunct and disjunct motion (with some guidelines suggested), the tendency tone (at this stage, only the leading tone), passing and neighbouring figures, and vertical and horizontal consonance and dissonance. The students understand that both circled notes in m.1 function as neighbours, although one is "dissonant" and the other "consonant." They therefore understand the bass note $\mathrm{E}$ on the third beat of $\mathrm{m} .1$ also as a quasineighbour embellishment of the tonic note. There may well be, even at this early stage, some classroom approach to the triadic implications of the two-voice counterpoint, but the passage makes its point about the embellishment of fundamental notes without that additional step.

It is important for the teacher to realize that a given technique need not be mastered either before one starts using it or before the next is discussed. (This is one of the crucial differences between undergraduate and graduate teaching: the graduate student is expected to achieve mastery of the material as it is taught.) When a concept or technique is introduced, the student can be made aware of some of its characteristics. Often, the student's musical instincts will lead him to find new and idiomatic usages, the classroom discussion of which then encourages his view that the study of theory can be a voyage of discovery rather than a tedious pilgrimage along a well-worn path. But even if his discoveries are not idiomatic, the experience can be both interesting and informative. Thus, the constant recurrence of even elementary details gives plenty of scope both for reinforcement and for expansion of previous knowledge. 
The essential features of Example 2B (which would appear in the classroom after some preliminary work with triads and Roman numerals) and their relation to Example $2 \mathrm{~A}$ hardly need discussion here. The events at "a" and " $b$ " are of particular interest: they will cause difficulty for the "conservatory harmonist" who will unthinkingly label them $\mathrm{V}^{6 / 4}$ and $\mathrm{V}^{7}$ respectively. However, some beginning student in the class will undoubtedly be able to explain the error; and only then should Handel's own figuration be shown. Example $2 \mathrm{C}$ shows a similar passage in a fuller texture. The student should have no difficulty, after the preparation of Example 2B, in realizing that the events at " $\mathrm{c}$ " and " $\mathrm{d}$ " are functionally identical although chordally different. Thus he learns easily that vii 6 is not just a substitute for $\mathrm{V}$, but is (at least in some cases) produced by a confluence of embellishing tones which elaborate or prolong the tonic, and thus are functionally subsidiary to that tonic. That in turn gives him a musically useful view of the dynamic shape of the phrase - the static prolonged tonic culminating in the (only) V, at the cadence. There need be no meaningless forest of Roman numerals on that student's assignments or in his mind. Further, once he understands the harmonic background, once he hears that the constant motion in the bass is merely embellishing the $F$ on the first beats of mm. 175, 177 and 179, he can easily understand that the melodic line is similarly embellishing the A which is coincident with our F; and then he truly hears that the passage harmonizes a 3-2-1 melodic descent with (only!) the harmonies I-V-I. He understands structure and prolongation, and knows why this passage is tonal.

Example 3a is considerably more complex than the excerpts of Example 2 , but it can be useful in a good first-year class in the second semester. Mm. 1-2 present little difficulty, but a lively discussion will be set off 


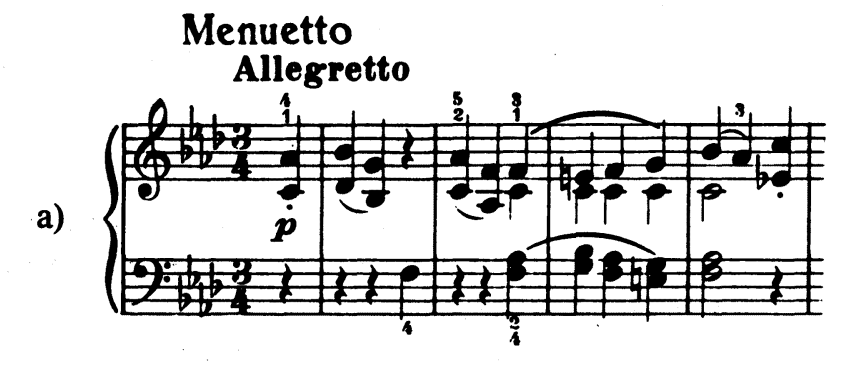

3

b)

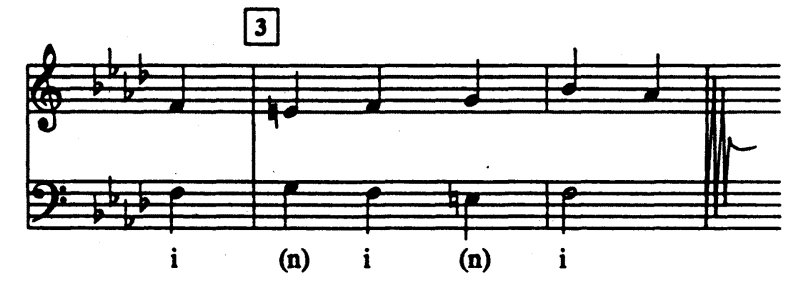

c)

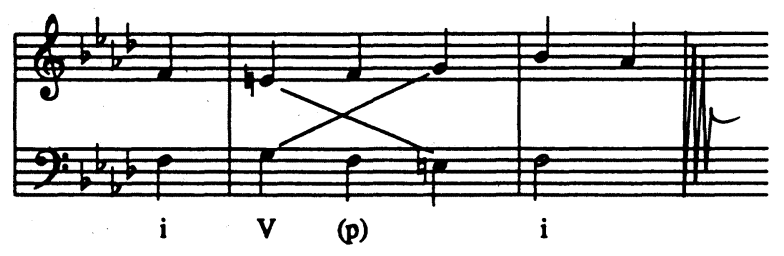

Figure 3. : Beethoven, Op.2(1)/III, mm. 1-4 : 
by mm. 2-4. The ultimate sense is of a contrapuntal prolongation of tonic. Examples $3 b$ and $3 c$ give two interpretations which the students will probably offer. The second, correct, reading illustrates beautifully the difference between a tonic chord and a tonic harmony. The distinction is here a very subtle one, but a carefully guided classroom discussion following much playing and listening, and informed by study of the rest of the minuet, can show why $3 \mathrm{c}$ is the preferable reading. In particular, points can be made about motivic generation, the perception of harmonic rhythm, and normative metric accentuation all of which speak against the analysis at $3 \mathrm{~b}$. Thus a piece which is probably too subtle and complex for home assignment can be the subject of an interesting and instructive class discussion.

The second year of tonal theory normally includes an expansion of the students' vocabulary and a deepening of their experience of tonal syntax. While the subjects for analysis will be longer and more chromatic, it is generally true that no really new principles are introduced and much of the classroom time can therefore be given to increasing the students' ability to cope with more subtle and complex analytic distinctions, and with larger aspects of form and structure. Example 4 shows a passage which can be discussed in conjunction with lessons on apparent seventh chords which arise strictly from voice-leading. We first understand the apparent IV 7 of $\mathrm{m} .1$ to be a chimera, produced by the suspension of $C$ in the upper voice. The $A$ a third lower in the "alto" voice similarly is a suspension with delayed resolution producing the apparent ii $6 / 5$. Finally, the $F$ in the "tenor" voice may be read as an upper neighbour to $\mathrm{E}$, and the harmonic meaning of the passage is as shown in Example 4e. In my own recent experience with this example, the only exception to the class's general understanding of the passage was that of a graduate student taking the course remedially. He labelled mm. 1-4 as follows: I - IV $7-\mathrm{ii}^{6 / 5}-\mathrm{vii}^{4 / 3}-\mathrm{vi}^{6 / 4}-\mathrm{I}$. He was only partially reformed by the music of Example 5, which makes the point very neatly through the motivic recurrence of the suspension figure; but his less taxonomic undergraduate colleagues did not simi larly confuse duration and function. 
a)

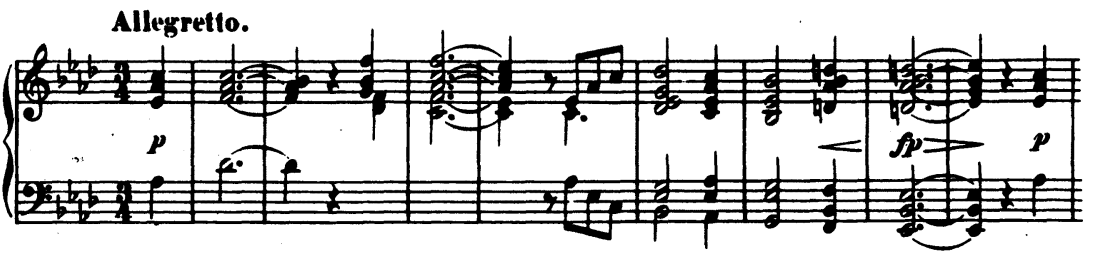

b)

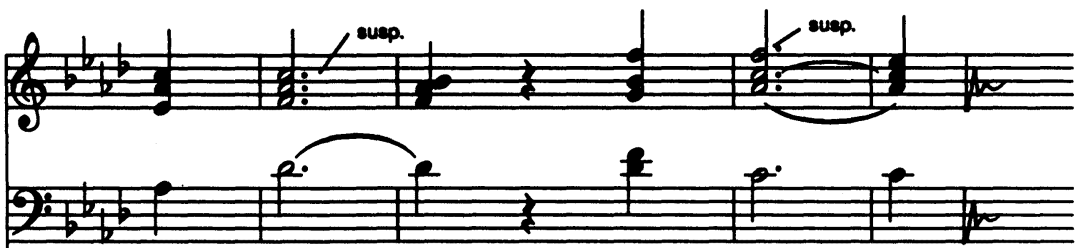

c)

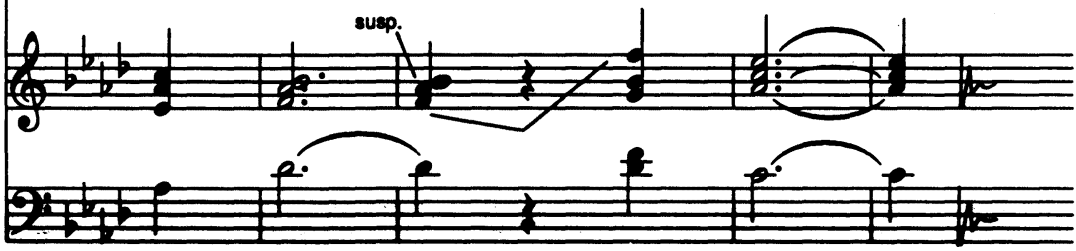

d)

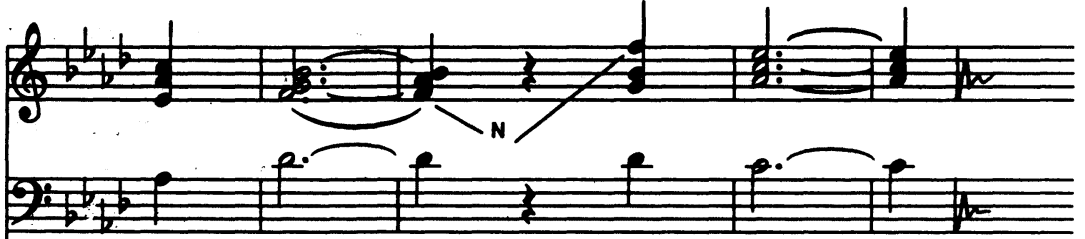

e)
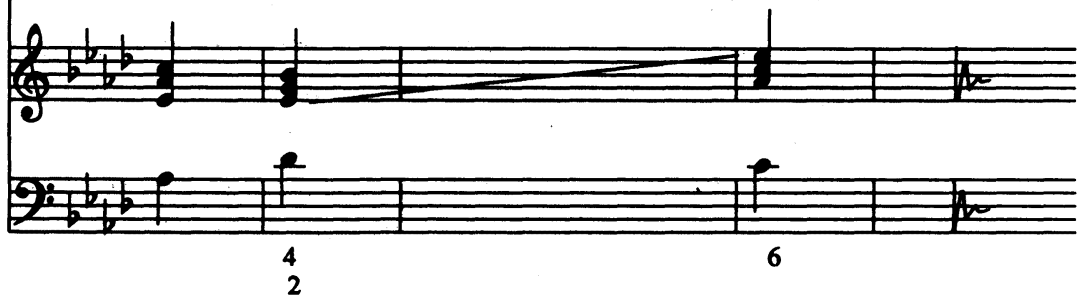

Figure 4. : Schubert, Op. 94/6. mm. 1-8 : 

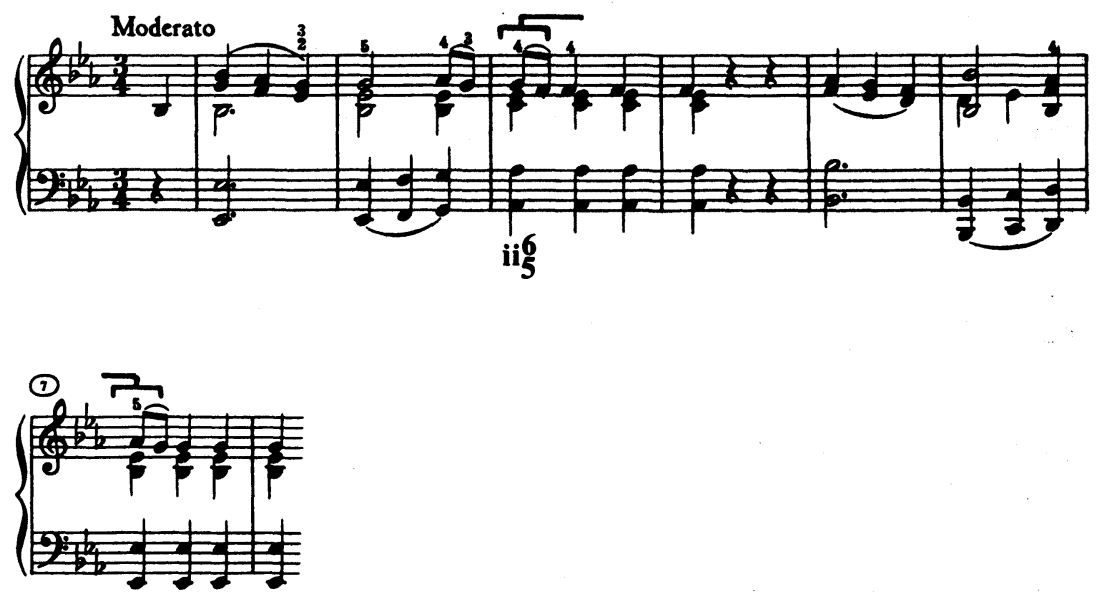

Figure 5. : Beethoven. Minuet. WoO 82, mm. 1-7. :

The chromatic vocabulary normally part of the sophomore curriculum can be approached in a similar manner - as chromatic embellishment of the underlying diatonic tonal syntax. Examples $6 \mathrm{a}, 6 \mathrm{~b}$, and $6 \mathrm{c}$ can be used in succession to make perfectly clear the harmonic meaning of the first measure of Schubert's "Am Meer." Examples 6a and 6b are of course mainly review material for the sophomore, but continuing reinforcement of old techniques in preparation for new ones should be a constant pedagogical practice. Because of the dissonance, the student easily hears that events " $a$ " and " $b$ " in Example $6 a$ are not in any sense chords, but merely complexes of neighbour notes. The parallel to events " $c$ " and "d" in Example $6 \mathrm{~b}$ can be quickly shown, even though in the Haydn example the neighbours result in consonant collections. Thus led to her own conclusions about the so-called German Sixth of "Am Meer," understanding that all of $\mathrm{mm} .1$ and 2 have a tonic func- 
tion embellished by chromatic neighbours, the student is prepared to deal with more conventional usages of the augmented sixth sonority.

a)

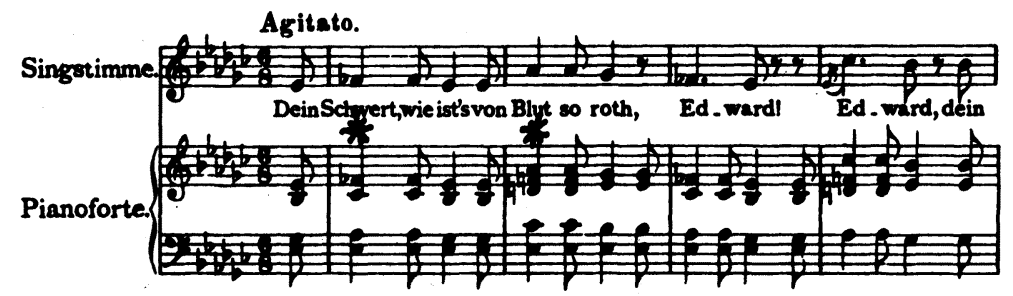

b)

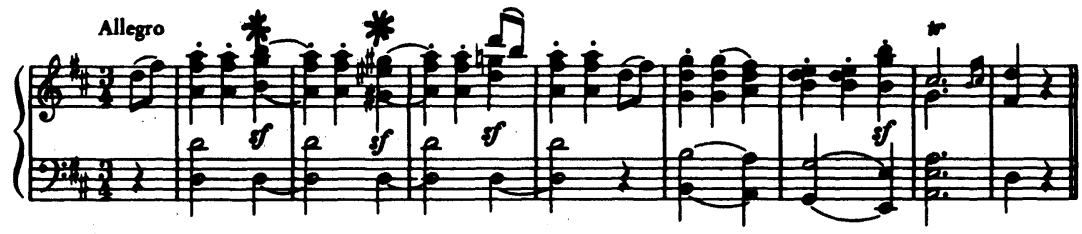

c)

Sehr langsam (Molto adagio)

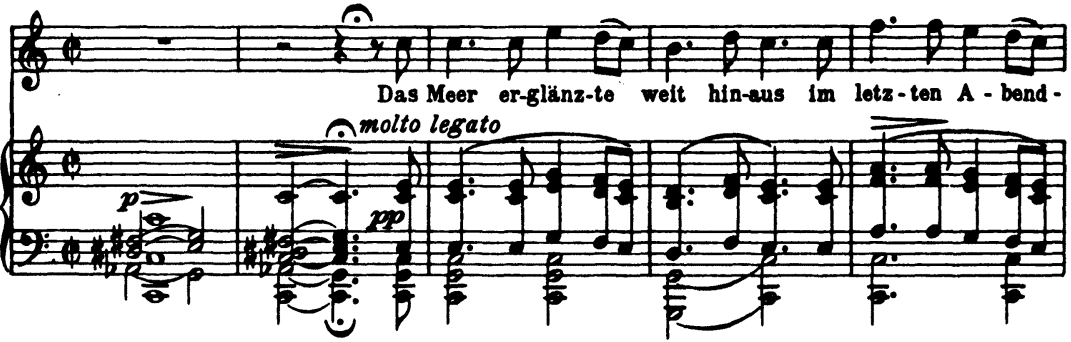

Figure 6. : a) Loewe, Edward, Op. 1(1), mm. 1-4; b) Haydn, Symphony 104/III, mm. 1-8; c) Schubert, Am Meer, mm. 1-5 : 
Taken step by step through the excerpts shown in Examples 7 and 8, she quickly understands the augmented sixth as a chromatic voiceleading embellishment of a (sometimes merely implied) diatonic harmony or harmonies. She can then proceed to written exercises exploring particular idiomatic procedures unencumbered by unnecessary terminologies. The sophomore analyst is fully capable of transcending chord labels and arriving at a reasonably sophisticated understanding of the derivation and the - at least - middleground sense of each of the illustrated usages. Tonal chromatic vocabulary can thus be demystified and made easily comprehensible within the already-known principles of diatonic practice; and the student so prepared will be able to recognize the fundamental revolution of the chromatic background when she encounters it in post-Romantic music. ${ }^{4}$
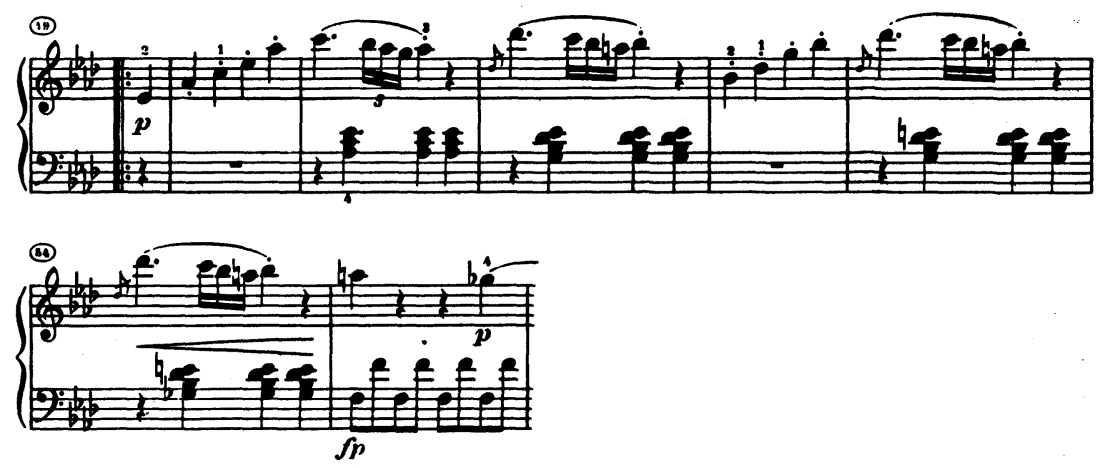

4 The teaching of that repertoire, music from roughly 1860 to 1920 , should be the subject of an essay far more extensive than this. 

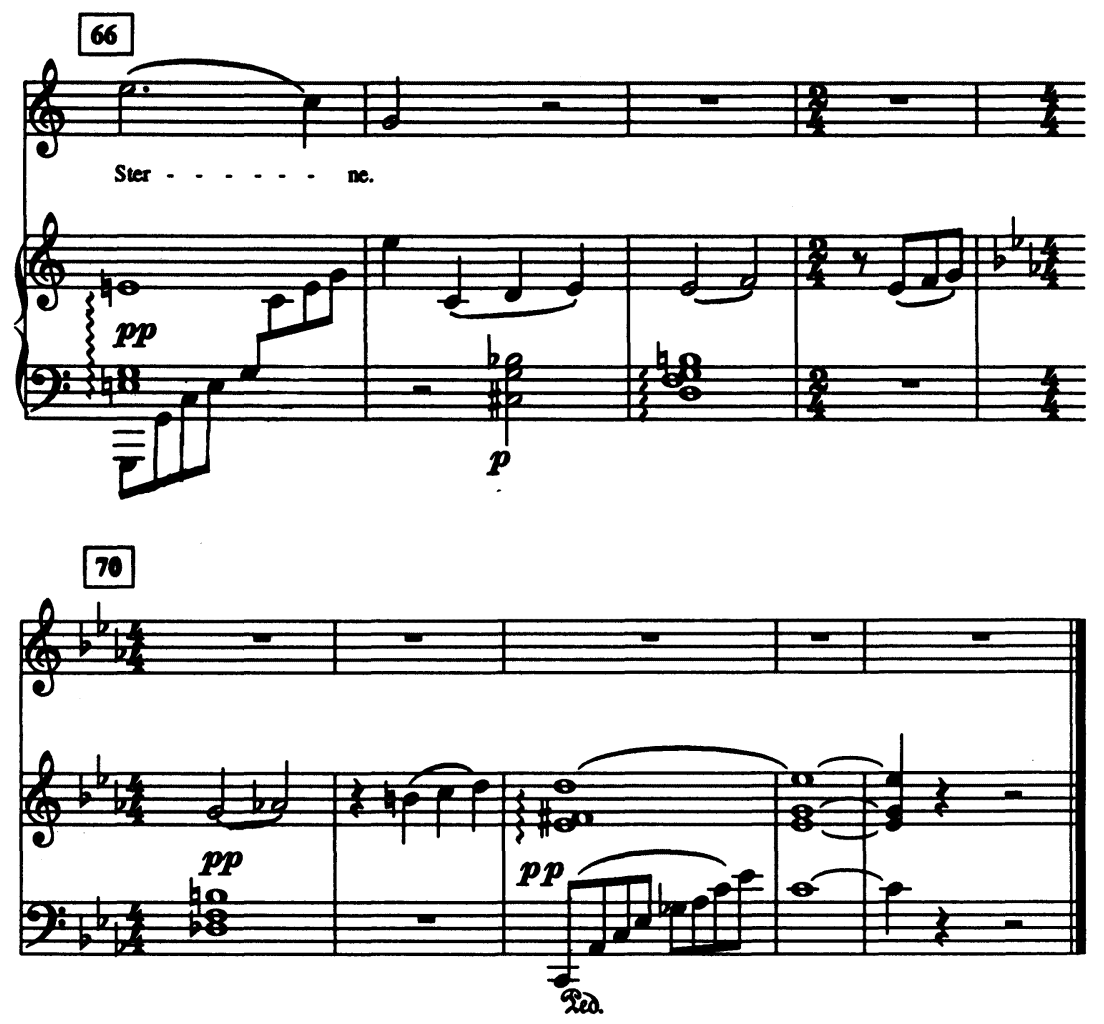

Figure 7. : a) Beethoven, Op. 2(1)/I, mm. 50-55; b) Mahler, "Nun seh' ich wohl", mm. 66-74. :

I have not yet found a way to instill in a freshman class any really refined analytic technique - that is to say, a set of guiding principles that will allow them confidently to approach a piece on its own terms. But in both first and second years, the usual descriptive generalities are 
not without value and should be part of the course material. Observations about design, surface elements of contrast and resemblance, melodic and harmonic continuity and interruption, conventional motivic description, all should be part of any discussion of any music used to illustrate syntactical techniques. Thus, the real goal of freshman analysis, transcending acquisition of technical knowledge, is to make the students aware that music can and should be thought about; that in every good piece of music there is always more than immediately meets the ear; and that just as careful hearing helps us to analyse, so intelligent analysis will improve our capacity to hear.

The purpose of analytical assignments is thus rather different from that of compositional work. While the latter primarily provide technical practice, the former should be conceived as real extensions of the processes of learning and thinking. Of course, one cannot simply require an undergraduate to "Analyse this piece" (as we can require him to "Label the chords in this piece"), since he normally lacks the experience to frame the right questions. Consequently, the labelling of harmonies, or phrases, or techniques should be merely the preliminary acts of an analysis guided by carefully directed questions. The student's attention can be drawn to points of analytic interest which he may be expected then to understand, though not necessarily to have uncovered for himself. 


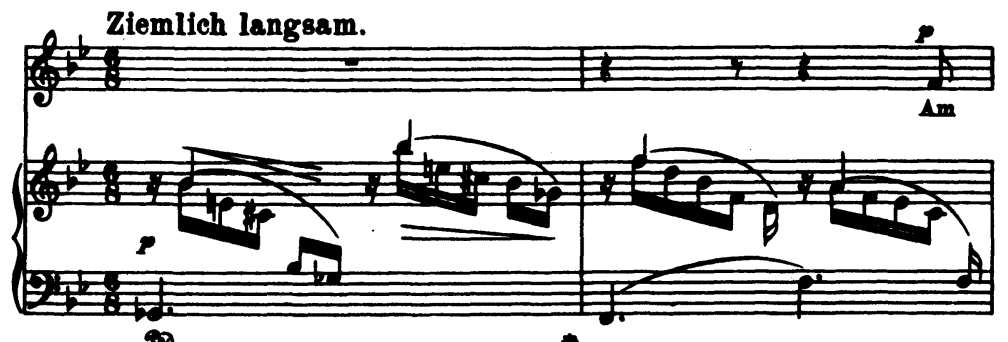

ata.
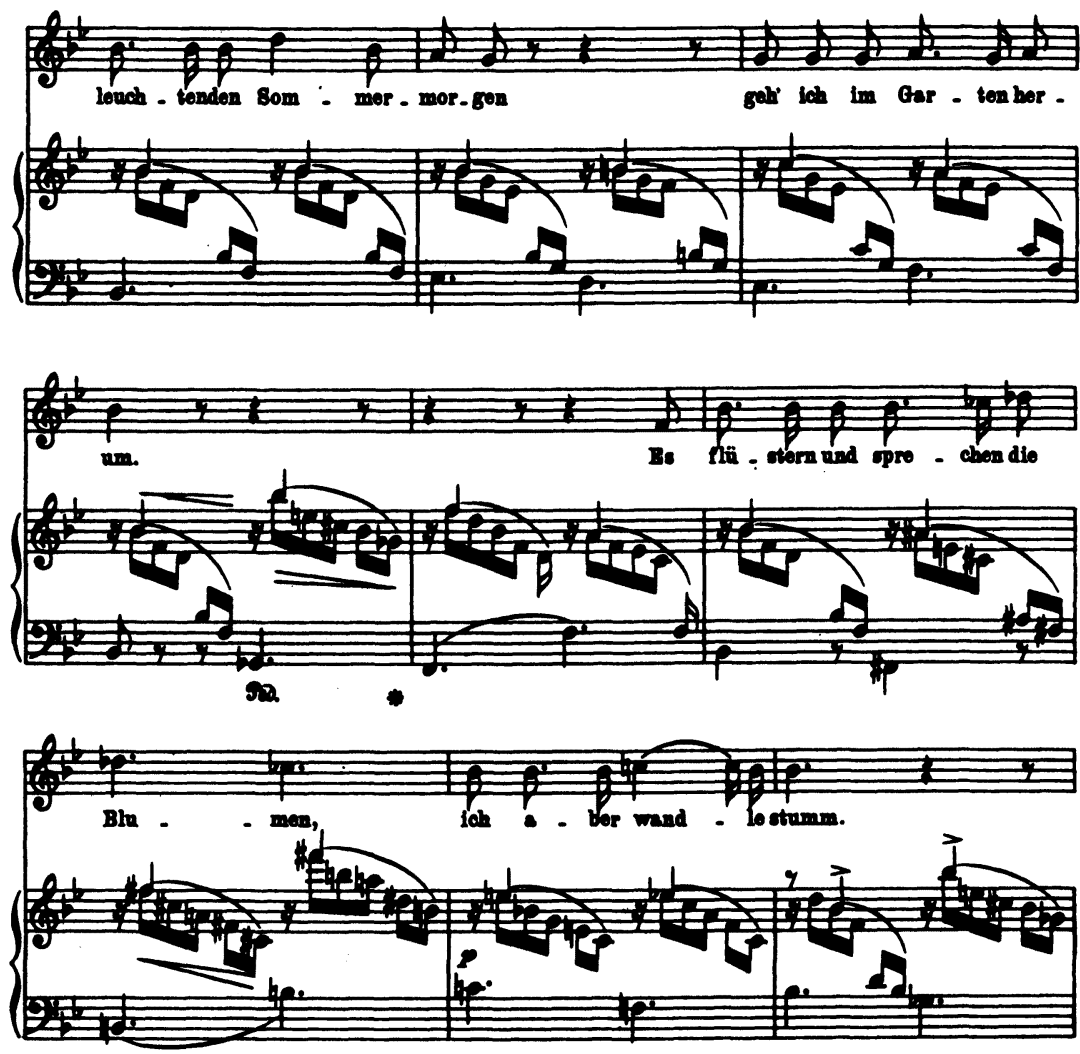

Figure 8. : Schumann, "Am leuchtenden Sommermorgen", mm. 1-11. : 

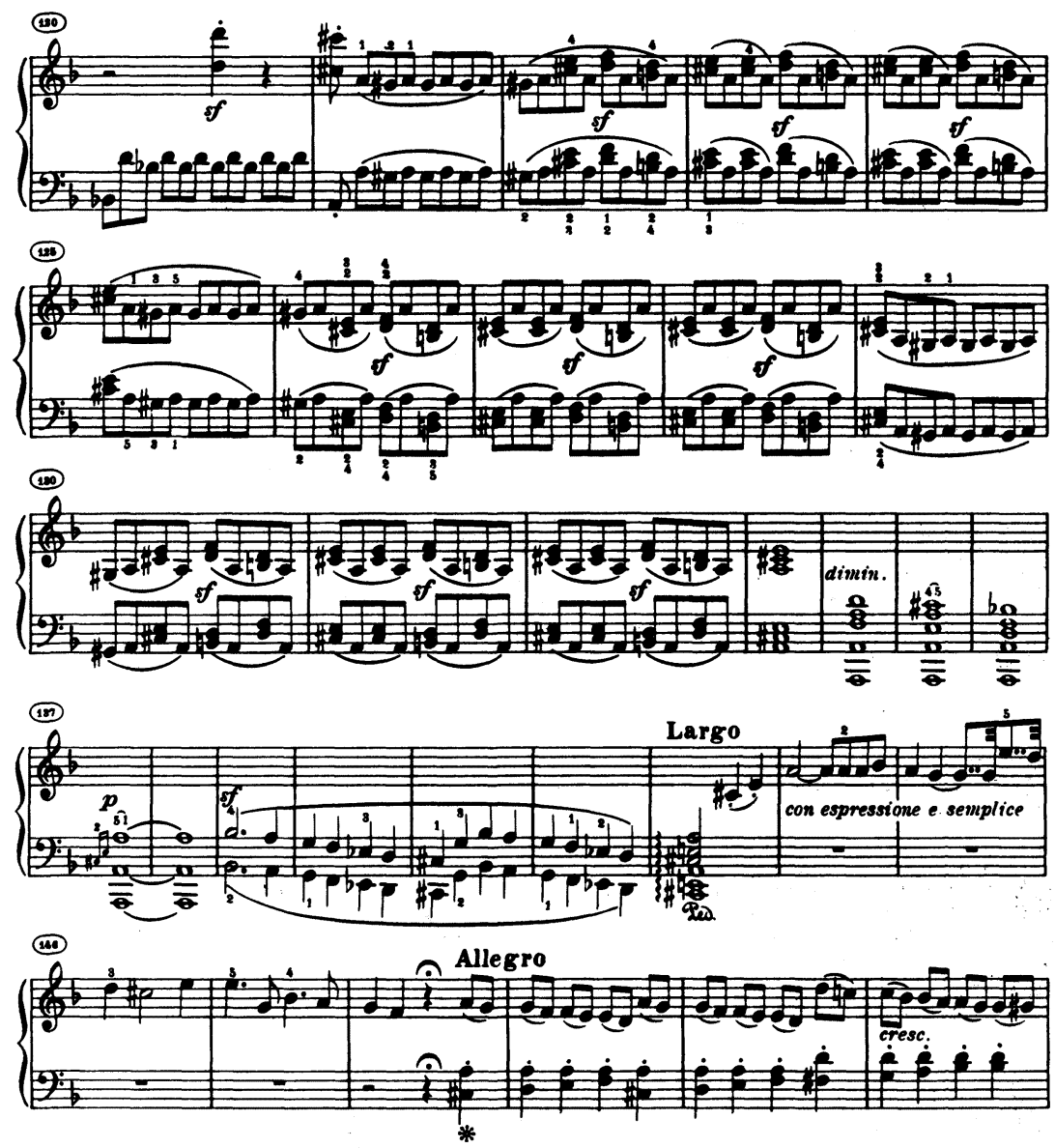

Figure 9. : Beethoven. Op. 31(2)/I, mm. 120-151. :

Example 9 shows the end of the development and the beginning of the recapitulation of Beethoven's Op. 31/2, first movement. Students should have no difficulty by the second term of the sophomore year in recognizing that $\mathrm{mm}$. 121-33 are a prolonged dominant; to stimulate further thought, we might ask exactly why the sforzando chords in 
mm. 123-25 and 127-29 are not functionally tonic; a slow class can be helped by advice first to examine mm. 130-32. Similarly, the students can be led to understand at least some of the implications of $\mathrm{mm}$. 133-43. We might ask: What is the purpose of the long note values in mm. 133-38? Measure 137 contains the only notated grace notes in the movement; what is their purpose? Note the sforzando chord in $\mathrm{m} .55$ [not shown in Example 9], which is answered in the recapitulation by the corresponding chord in $\mathrm{m}$. 185. What are these two chords? Is their local usage idiomatic? What is the significance of the tonal relationship between them? How is this foreshadowed in m. 133-43? and so on. All the preceding questions have deliberately been culled from a published analysis directed at skilled theorists (Kamien 1976:228-235), to show that difficult analytical concepts can be made suitable for undergraduate consumption. The scope is limited only by the instructor's imagination and knowledge of the literature. We might draw attention to the tonal design of $\mathrm{mm} .1-20$, of $\mathrm{mm}$. 1-87 and to a comparison of the two; or to a comparison of the processes of $\mathrm{mm}$. 13-20, 87-133 and 121-133; or to the various manifestations of the diminished third (or augmented sixth) first stated in $\mathrm{m}$. 6; or to many other salient features of the work, all of which are essential to its compositional coherence, and all of which can be comprehended by an undergraduate student prepared to understand structural levels, linear processes and prolongational techniques. A student who is not capable, and who may never become capable, of graphing or otherwise analysing the work in detail can nevertheless achieve a great understanding of significant features of its language and design. More, he can be led to discover many of these beauties for himself, and such a student will never be suspicious that the study of music theory is an onerous chore to be suffered only because it is a degree requirement.

By being exposed to real music and real musical problems from her very first theory class, the student is made aware that musical understanding requires the cooperation of intuition and intellect. She acquires not only the foundation of a technical knowledge that will be of use whether or not she proceeds to advanced theoretical study, but also the habit of thinking about music in ways which are conceptually accurate, intellectually stimulating, and musically relevant. There need be no 
conflict between the theorist's desire for analytic insight and the teacher's need for pedagogical practicality: the two can unite to provide a fundamental music-theoretical training that will also be an effective preparation for advanced Schenkerian study.

\section{REFERENCES}

ALDWELL, E. \& SCHACHTER, C.

1978: Harmony and Voice Leading. New York: Harcourt Brace Jovanovich.

BEACH, D.

1983: "Schenker's Theories: A Pedagogical View," in Aspects of Schenkerian Theory, ed. D. Beach. New Haven: Yale University Press, pp. 1-38.

FORTE, A \& GILBERT, S.

1982: Introduction to Schenkerian Analysis. New York: Norton.

JONAS, 0 .

1982: Introduction to the Theory of Heinrich Schenker, trans. \& ed. J. Rothgeb. New York: Longman.

KAMIEN, $R$.

1976: "Aspects of the Recapitulation in Beethoven," The Music Forum IV: 195-235.

KOSTKA, S. \& PAYNE, D.

1984: Tonal Harmony. New York: Alfred A. Knopf.

KRAFTT, L.

1987: Gradus, 2nd edn. New York: Norton.

LESTER, $\mathbf{J}$.

1982: Harmony in Tonal Music. New York: Alfred A. Knopf.

ROTHGEB, J.

1981: "Schenkerian Theory: Its Implications for the Undergraduate Curriculum," Music Theory Spectrum, III: 142-149.

SCHENKER, $\mathrm{H}$.

1978: Free Composition, trans. E. Oster, 2 vols. New York: Longman. 